P.O. Box 8004

Wichita, Kansas

$11 / 4 / 76$

KENT:

I think this issue of IR is going to be fun, don't you? All my friends are busy with their pieces. But you, Kent, I didn't expect you. I know you still don't believe me about that ancient unpleasantness at the Fontainebleau, but the story hasn't changed: Errin did come along at the last minute as the babysitter; my wife did happen to be out shopping that day; the kids were at a movie in the hotel; you saw the bellhop before I did; we were only sunbathing (everyone got used to her going around like that at the TV station, I didn't even notice any more). I finally settled out of court with the hotel, by the way, you might be glad to hear that. Errin, predictable as ever, went on to Japan from Wichita; no word in the past three years.

As for "Ossa" and life between inverted commas, well, here's the copy of “Ossa Eats Doilies, Some Say Antimacassars" that you asked for. It's a pity you didn't read it more carefully six years ago. I swear I thought that you were putting me on-all those poems and love letters, old pen-is-pal!-or that we were collaborating on something, like a story. Anyway, here it isand at least the chocolates were real, eh?

Good luck with the epistolary blague. I just hope you can say something awful about me without trying to be funny about it. That's all I ask.

Was at Tony Sobin's house last night for a birthday supper of the woman he lives with. Her name is Teddi Todd and she's the current editor of MIKROKOSMOS. Why don't you send something, c/o English Department. It will get to her (I promise). Check it out ...

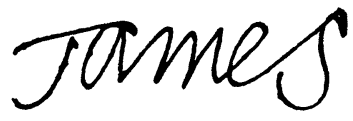

\title{
In Le Bardo There Is a Head of Jupiter as Tall as a Woman / James Mechem
}

I'm a travel writer who hates to travel. It's true. If there's one thing I hate worse than traveling it's being a tourist. 
But one has to make a living.

I try to pay as little attention to my surroundings as possible. It's something perverse in me that I dearly love.

After ten days I look for a photographer and when the pictures are ready I write my article at the scene. That's how I manage to stay alive. I could be rich if I wanted to kill myself.

I got wind of a story I might like to work on about a woman who ruled Tunis in antiquity.

She rode in battle and lost her head. There have been women who have ruled by intrigue, but few who have ruled by derring-do. Instead of sending her troops out to battle she rode at the head of them. She was slain in the saddle, her head chopped off. It was sent by messenger to the caliph.

Bring me her head, the caliph had said. I found this story in my research in Tunis. Hand-to-hand combat in the saddle, her head rolled among the legs of the horses, came to rest, one ear to the ground, the nose leaking blood, the hair messed with manure. I was going to have to write this story at all costs. Wild horses couldn't keep me from it and I didn't want to be kept from it.

The queen came to me in a dream my third night in Tunis.

Tall and beautiful but her head was on backwards. I leapt out of bed and ran from the room.

When I mustered the courage to return to my bed she was gone. A strand of black hair that I found on my pillow was all that remained of her visit. I dropped it into an envelope and mailed it to myself. In my dream it seemed like the thing to do.

She had no name. She has come down through history as the Prophetess (Kahena).

I quenched my enthusiasm with a week of reading and that seemed to be that. I went to meet my photographer.

She came with strong recommendation by the American Embassy as a former Peace Corps worker. The samples she showed me of her work convinced me that I should hire her and I did.

She tried to talk to me about cameras. But I told her to use whatever camera she thought best and I wasn't interested in hearing about them-I had already heard too much about cameras. She asked what I was interested in talking about and I told her that if she would confine herself to answering questions we would get along fine. That seemed to work because right away she began pointing her camera at things.

She shot pictures of caves, olive groves, salt lakes, ruins, orchards. It took us a week to cover the ground. I would get up each morning at ten and have breakfast and wait on her.

I told her nothing, but on the third day as we were standing in a field she 
said, It was somewhere around here that Queen Kahena fell in battle. Tell me about her, I said.

A famous poem describes her as "apple-bosomed with piercing black eyes."

It was an irrigated field we were standing in reclaimed from the desert. Pitched battles on the steppes. The blood of centuries underfoot. Judy's camera clicked. She stooped and picked a rose out of the soil. And that afternoon in the Great Mosque she talked about the roses of Tunisia, exposing roll after roll of film.

We spent the next day in the capital photographing public buildings and fine women, fountains and beautiful shops. At lunch I said, I wonder if you can find a woman with piercing eyes and apple bosoms.

She was loading film in her camera.

I said I'd like to have every woman in the story have apple eyes and piercing bosoms.

That would be far out. She snapped the case shut.

I can leave most scenic sights alone but the beach at Djerba was different. I sat down under a beach umbrella and trailed my hand in the sand. It reminded me of so many places, in Portugal, Hawaii, le Midi . . .

We've been working ten days, Judy said.

You remember the Lotus Eaters. Ulysses was shipwrecked here. She only shrugged. When we got back to Tunis it was dark and the sidewalk cafes were crowded with coffee drinkers. And we had a coffee before we went up to bed.

My writing seems to me to be what you said of Salinger-nothing to say. It's because I really have nothing to say. I don't believe that's (i.e., content important) the kind of novelist I want to be. I want to be like Salinger and write slick patter. I want the virtue of the story to be in the telling not the story ... I want something like Hemingway, you can't stop reading it until you're done, not because of the plot, not because of the symbolism, but because of the excitement of the words themselves ... I want to turn words into magic or make an impossible situation believable by the right turn of phrase. Like some movies do. Like S. J. Perelman does. Get it down exactly in a few words like Sylvia Townsend Warner. Every word seems rambling but every word counts. Every word stands for a hundred when she writes. Aimless, oblique, but closing in fast ... I just read Jacqueline Susann's Dolores. Very good writer. Why did they not see it-the critics-how can they deify stupid writers like Bellow and Updike and Styron and vilify really good writers like Susann? Or am I missing something? She writes a lot 
like James M. Cain ... She writes like me. I have to stop every once in awhile to read a sentence over again it is so much like one of my sentences. Uses three dots liberally-iust like me and Celine ... John Cage suggests that the hard work of the serious artist is equivalent to playing chess. Why do you play chess all the time, I can hear some father saying. It's time to grow up and go to work. Like somebody might have told Fragonard, Drop that pink paint brush! Or Mozart? Why must you always compose in pink? ... Mozart, your nudes will live after you. Edith Oravez has brought them to life. Drop your pink brush. That's what people tell me. Lafe said, But how does your hero make his money? But I'm on the ground floor of the revolution of the novel. More Junol Catullus' title. That's all right. Something was going on then. I thought it was over and I was only hanging on, that's what I thought, kicking a dead horse. I should know better. I told myself a long time ago. Keep kicking the dead horse. You never know where you might get tol I told myself! The modern novel a monster. RobbeGrillet has puffed me full of confidence. Yes, yes, I'm an exponent of the nouveau roman ... any school that will have me ... my own influence felt around here ... I hope it widens ... a celestial body... exploding, spiraling nova ... that's me ... on fire ... yeah yeah yeah! Going for bear, yeah! Into the fray ... and all of that ... back to back ... coming going along ... I like it like that ... Celine has shown us how ... (from letters to the editor and "Renata Is Crying: A Nostalgia for Mona and Those Times")

\section{Some Big Broad / James Mechem}

Some broad I'd say on first catching a glimpse of the Twin Volcanoes, the Platinum Hair, the Imposing Dimensions, the Fine Figure of The Woman. And more often than not I'd faint dead away at her Feet. Those Smoldering Twin Volcanoes Would Overpower Me, you see. And I'd be done for, more often than not, you see. "What a broad!" I would exclaim and faint dead away, swoon practically in her arms. "Who is this buffoon who keeps doing this?" she asked finally after the fourteenth occurrence.

Naturally I was unable to answer, struck dumb as I was, groveling in ecstasy at her feet, delicately sidestepping as she had learned to do when my tactics became troublesome.

"I suggest you lock this Man up," she said. "Put him away. He's an eye- 